\title{
Ashta Bhumi, Panduan Pembuatan Lay Out Ruang Bangunan Hunian Rumah Tinggal Tradisional Bali Madya
}

\author{
Anak Agung Gede Rai Remawa ${ }^{1}$, Cok Gde Rai Padmanaba ${ }^{2}$ \\ Jurusan /Program Studi Desain Interior, Fakultas Seni Rupa dan Desain, Institut Seni Indonesia Denpasar. \\ Iremava@ymail.com
}

\begin{abstract}
Ashta Bhumi adalah pengetahuan yang membahas tentang konsep ruang yang bersumber dari lontar, khususnya yang berhubungan dengan perancangan lay out ruang pekarangan di dalam bangunan hunian rumah tinggal tradisional Bali Madya. Sistem pengukuran jaraknya menggunakan satuan depa dan tapak yang diambil dari ukuran tubuh, tangan dan telapak kaki kepala keluarga laki-laki. Dasar pengukuran pekarangan huniannya menggunakan satuan depa-hasta-musti atau kelipatannya yang terdiri dari; ukuran Gajah (15x14), Dwaja (14x13), Singa (13x12) dan Wreksa (12x11). Beragamnya jenis ukuran yang terdapat pada hunian Bali Madya, adalah masalah yang sangat kompleks, maka dari itu penelitian ini akan mengamati dan meneliti jenis ukuran Gajah (sukat Gajah), Dwaja (sukat Dwaja), Singa (sukat Singa) dan Wreksa (sukat Wreksa). Ukuran ini banyak diterapkan oleh masyarakat tradisional Bali, karena digunakan oleh kalangan masyarakat luas. Setelah pengukuran tahap pertama ini, kemudian dilanjutkan dengan pengukuran berikutnya yaitu Sukat Pah Pinara Sanga, Sukat Tampak, Sukat Tampak Ngandang, dan Sukat Tampak Guli, untuk menentukan keluasan dan pembagian areal pekarangannya serta jarak antara bangunannya. Penelitian ini menggunakan metode deskriptif analitik dan bersifat kualitatif dengan pendekatan etnosains (etnografi), untuk mengetahui bagaimana masyarakat mengorganisir budayanya, sebagai sebuah konsep ruang masa lalu. Hasil dan manfaat dari penelitian ini adalah untuk mengetahui dasar pembentukan lay out ruang pekarangan dalam bangunan hunian rumah tinggal tradisional Bali Madya.
\end{abstract}

Kata kunci: Ashta Bhumi, Pah Pinara Sanga, Depa,Hasta dan Tapak.

\section{Ashta Bhumi, Guide to Designing Dwelling Space's Lay Out of Traditional Bali Madya Residential Buildings}

Ashta Bhumi is knowledge that discusses the concept of space that originated from lontar, especially those related to the lay out design of yard in traditional Bali Madya dwelling buildings. The distance measurement system uses depa and tapak units which are taken from the body size, hands and feet of the male family head. The basis for measuring the residential area uses the depa-hasta-musti unit or its multiples consisting of; sizes of Gajah (15x14), Dwaja (14x13), Singa (13x12) and Wreksa (12x11). The various types of sizes found in Bali Madya dwellings are a very complex problem, therefore this study will observe and examine the size types of Gajah (Sukat Gajah), Dwaja (Sukat Dwaja), Singa (Sukat Singa) and Wreksa (Sukat Wreksa). This measurement is widely applied by traditional Balinese society, because it is used by the community at large. After this first stage measurement, continued with Sukat Pah Pinara Sanga, Sukat Tampak, Sukat Tampak Ngandang, and Sukat Tampak Guli, to determine the extent and division of the area of the yard and the distance between the buildings. This research uses descriptive analytic and qualitative methods with an ethnoscience (ethnographic) approach, to find out how society organizes its culture, as a concept of space in the old days. The results and benefits of this study are to determine the basis for the formation space lay out of yard in dwelling space of traditional Bali Madya residential buildings.

Keywords: Ashta Bhumi, Pah Pinara Sanga, Depa,Hasta and Tapak.

Proses Review : 2 - 28 Januari 2021, Dinyatakan Lolos: 16 Februari 2021 


\section{PENDAHULUAN}

Bali sebagai salah satu daerah dengan keunikan khusus telah diurai dalam "Pulwa Bali" dan telah dikenal istilahnya sejak tahun 95 Çaka atau tahun 173 Masehi (lontar Usana Bali). Kemudian dalam perkembangan arsitekturnya, Bali telah mengalami lima masa yang dikenal dengan masa Bali Mula (Bali Awal), Bali Aga (Bali Pegunungan), Bali Madya (Bali Majapahit/Bali Tengah), Bali Kolonial dan Bali Modern (Gelebet, 1982;19). Penelitian yang memilih Bali Madya sebagai topik pembahasan konsep tradisional dipandang tepat, karena pada masa Bali Madya ini, Bali mengalami puncak keseniannya dan masih berpengaruh sampai sekarang. Berbagai kesenian seperti seni tabuh, seni tari, seni lukis, seni ukir dan tidak ketinggalan seni arsitektur, berkembang sangat pesat pada masa Bali Madya. Pada masa ini muncul arsitek besar Danghyang Nirartha yang menyempurnakan konsep pendahulunya Empu Kuturan dan Kebo Iwa. Tokoh-tokoh terkenal ini telah menciptakan berbagai konsep ruang yang berhubungan dengan hunian bangunan tradisional seperti hunian rumah tinggal tradisional Bali Aga dan Bali Madya. Konsep pengetahuan ini tercatat dalam beberapa lontar seperti; Ashta Kosala Kosali, Ashta Bhumi, Wiswakarma, Dharma Laksana, Sukat Karang, Katuturan Sanghyang Anala, Wariga Garga dan lain sebagainya.

\section{METODOLOGI}

Peneliti menggunakan analisis kualitatif sebagai basis grounded theory (Endraswara, 2006:71). Untuk menentukan sumber lontar mana yang akan digunakan, atau memilih salah satunya. Metoda analisis ini berguna untuk mengembangkan konseptualisasi teoritik berdasarkan data yang diperoleh di lapangan. Peneliti memilih 28 jenis lontar sebagai dokumen lapangan dan menyusunnya kembali sesuai metode analisis yang disaratkan dalam etnosains (etnografi) yaitu grounded teory. Ke 28 sumber lontar yang diambil dari berbagai daerah ini dianggap representatif untuk menjelaskan berbagai hal tentang sistem dan proses pembangunan hunian Bali Madya yang berdasarkan ukuran Sukat Depa Hasta Musti dan seterusnya disingkat dengan (SDHM). Berdasarkan data lontar yang ditemukan di lapangan, peneliti menyusun berbagai rangkaian konsep, menjadi teori baru yang lebih lengkap dengan istilah dan nama yang tidak berbeda-beda. Konsep dibangun dan dikembangkan lebih analitis, jelas dan meyakinkan, untuk menghasilkan konsep baru dengan cara pengkodean; terbuka, berporos (aksial) dan selektif (Endraswara, 2006:72). Untuk memperjelas konsep di atas, peneliti menyajikannya dalam berbagai gambar, sehingga mudah untuk dipahami. Dengan demikian, maka masyarakat umum akan lebih mudah mempelajari, mencerap, menerapkan dan mengembangkannya pada masa yang akan datang. Setelah dilakukan pengkodean terbuka, kemudian dilanjutkan dengan pengkodean berporos (aksial), dan dilakukan dengan analisis yang lebih mendalam pada salah satu kategori untuk menghasilkan pengetahuan komulatif yang penting dalam proses pengkategorian data ini. Proses terakhir dari penelitian yang menggunakan metode analisis ini, adalah melakukan pengkodean selektif untuk menentukan grounded theory, dan pada saat ini peneliti telah memperoleh kategori yang mantap dalam kejelasan sifat, dimensi serta hubungan paradigmatik antar kategori yang diteliti, sehingga dapat merumuskannya dalam urutan yang logis.

\section{BAHASAN DAN ANALISIS}

Berbagai lontar Ashta Bhumi dan Ashta Kosali, Dharma Laksana serta Wariga Garga menyebutkan bahwa sistem pengukuran area rumah (lay out pekarangan) adalah menggunakan satuan depa (depa alit, depa madya dan depa agung). Ukuran ini ditambahkan lagi dengan sebutan se hasta (dari siku sampai ujung jari tangan) dan se musti (satu kepal tangan dan ibu jari didirikan). Sistem pengukurannya dibagi menjadi empat bagian yang memiliki sebutan: Gajah, Dwaja, Singa dan Wreksa. Areal dengan ukuran 15x14 DHM disebut Gajah, areal dengan ukuran 14x13 DHM disebut Dwaja, areal dengan ukuran 13x12 DHM disebut Singa dan areal dengan ukuran 12x11 DHM disebut Wreksa. Perhitungan ini dapat diteruskan kepada ukuran yang lebih kecil seperti; 11x10 (Gajah), 10x9 (Dwaja), 9x8 (Singa) dan 8x7 (Wreksa) dan seterusnya atau sebaliknya diteuskan ke ukuran yang lebih besar sesuai ketersediaan besaran lahan. Sesuai namanya, ukuran-ukuran ini difungsikan untuk keperluan ukuran yang berbeda. Ukuran Gajah adalah untuk rumah Brahmana, Pedanda, Wiku dan Bujangga (pendeta), ukuran Dwaja adalah untuk tempat/stana Batara/Dewa (parahyangan, penataran, pejenengan, pemerajan, sanggar), Singa adalah untuk rumah Satria, Wesya dan Wreksa adalah untuk rumah Sudra, Prabali, Prabekel, Pande, Wong Tani, dan Pakatik.

\section{Konsep dan Filosofi Ashta Bhumi}

Salah satu dasar pengaturan lay out ruang dalam perancangan hunian Bali Madya, adalah dengan pengaturan sonasi (pendaerahan). Ashta Bhumi adalah merancang area yang ada di atas permukaan tanah (bumi) atau medesain sonasi di atas tanah. Pengukurannya dilakukan dengan depa yaitu ukuran sepanjang kedua belah tangan mendepang dari ujung jari tengah tangan kiri sampai ke ujung jari tengah tangan kanan (Lukman Ali, 1994: 224). Disamping menggunakan bentangan tangan dalam Ashta Bhumi, ujung kaki juga termasuk ke dalam perhitungan depa, khususnya untuk ukuran depa agung. Sarana pengukuran berikutnya adalah tampak/tapak (ukuran dengan telapak kaki) yang terdiri dari tampak (panjang telapak kaki) dan tampak ngandang (lebar telapak kaki). Ukurannya diambil dari tangan dan kaki penghuni tertua sebagai pemilik hunian tersebut.

Proses dan upacara pembukaan lahannya dilakukan 

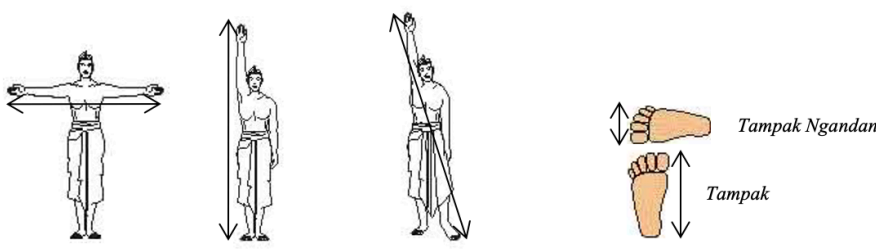

1. Depa Alit

2. Depa Madya

3. Depa Agung

Gambar 1. Ukuran Depa (alit, madya, agung) dan Tapak (tampak)

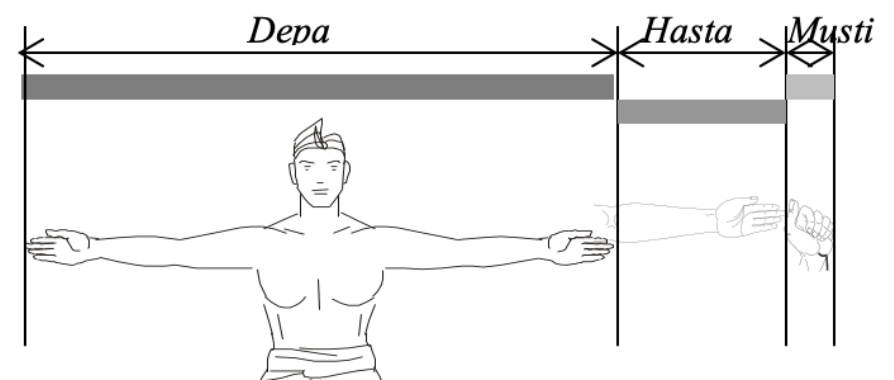

Gambar 2. Sistem pengukuran SDHM (sukat depa+hasta+musti)

dengan beberapa tahapan yang disebut: 1). ngruak karang (membuka lahan), 2). nyukat karang (mengukur lahan), 3). nasarin (membuat dasar pondasi), 4). memakuh (mendirikan tiang bangunan), dan 5). melaspas (mengupacarai). Pada saat akan membuka lahan, didahului dengan upacara sederhana dan kemudian dilakukan pengukuran awal (nyukat karang) dengan menggunakan ukuran anggota badan pemilik bangunan yang paling dituakan dalam keluarga.

\section{Konsep Sukat Depa-Hasta-Musti (SDHM)}

Setelah upacara pembukaan lahan, tahap berikutnya dilakukan pengukuran dengan menggunakan depa dan tampak seperti yang tersurat dalam lontar Ashta Bhumi tersebut. Berbagai sebutan ukurannya adalah; Gajah, Dwaja, Singa dan Wreksa. Masing-masing besaran ukurannya; Gajah (ukuran 15x14 DHM), Dwaja (ukuran14x13 DHM), Singa (ukuran 13x12 DHM) dan Wreksa (ukuran 12x11 DHM) serta kelipatan seterusnya. Keempat nama ukuran ini, besaran ukurannya dapat bervariasi, tetapi namanya akan tetap sama seperti ukuran sebelumnya. Selain nama di atas masih ada sebutan nama lainnya seperti; lembu, linggaha, lingga pusa dan gajah amerta, namun nama ini jarang digunakan. Panjang ukurannya, dapat menggunakan depa alit, depa madya, atau depa agung dengan tambahan se hasta dan se musti. Sistem pengukuran ini dikenal dengan sebutan Sukat Depa-Hasta-Musti (SDHM). Ukuran dengan berbagai perhitungan yang menggunakan modul anggota tubuh penghuni, penerapan dan pilihan ukurannya dilakukan sesuai dengan ketersediaan lahan.

Pengertian sistem ukuran depa-hasta-musti, adalah panjang dari rentangan tangan penghuni (depa alit, madya, dan depa agung), ditambah dengan ukuran panjang dari siku sampai ke ujung jari telapak tangan (hasta), dengan pengurip satu genggaman tangan dengan ibu jari ditegakkan (musti). Pengukuran dasar ini digunakan untuk menentukan ukuran yang disebut Gajah, Dwaja, Singa dan Wreksa. Model ini adalah ukuran hunian yang telah diatur dalam lontar sesuai profesi dan warnanya. Lebih jelasnya lihat gambar 2 di bawah. Setelah menyelesaikan pengukuran awal ini, kemudian dilanjutkan dengan pengukuran pembagian pintu keluar yang disebut konsep pah pinara sanga (panjang/lebar areal dibagi sembilan) dan pengukuran keluasan halaman dengan menggunakan sukat natar/ natah, seperti data lontar yang diperoleh di lapangan sebagai berikut.

Sistem pengukuran DHM ini terdiri dari tiga model, yaitu ukuran depa alit (a), depa madya (b) dan depa agung (c). Ukuran kecil-sedang dan besar ini, dipilih sesuai dengan ketersediaan lahan yang dimiliki penghuni. Semakin luas areanya maka akan menggunakan satuan depa agung dan begitu juga sebaliknya. Untuk memperjelas aplikasinya akan diambil satu contoh terkecil pengukuran lahan pada hasil pengkodean ini, yang disebut ukuran Wreksa (4x3 DHM) yang divisualisasikan dalam gambar 3(a) dan 4 berikut.

Setelah diketahui tempat dan luas lahan yang akan diukur, maka pada saat mengukur area pekarangan (nyukat karang), dilakukan pengukuran dengan menggunakan depa alit, depa madya atau depa agung (Gelebet, 1985: 31). Kalau lahannya kecil menggunakan depa alit, bila lahannya sedang menggunakan depa madya dan apabila lahannya luas maka akan menggunakan depa agung atau kalau sangat luas akan menggunakan kelipatan dari masing-masing ukuran pada ketiga model ukuran tersebut. Tahap pertama dilakukan pengukuran dari bagian Selatan ke Utara dan selanjutnya dari bagian Barat ke Timur, dari Utara ke Selatan dan dari Timur ke Barat dengan menggunakan pengukuran SDHM yang dilakukan sesuai perputaran jarum jam (mangalor-mangetan). Hasil pengukurannya dapat dilihat pada gambar 4.

Hasil penelitian sistem pengukuran DHM dapat diuraikan selengkapnya pada tabel 1 .

Tabel 1. Hasil Ukuran Sukat Depa-Hasta-Musti (SDHM)

\begin{tabular}{ccccl} 
No Ukuran & Nama & Makna & Fungsi \\
\hline & & & & \\
1 & $15 \times 14$ & Gajah & $\begin{array}{l}\text { Ayu } \\
\text { (baik) }\end{array}$ & $\begin{array}{l}\text { Rumah untuk: } \\
\text { Brahmana, Bujangga, } \\
\text { Pandita, Wiku, Ulaka }\end{array}$
\end{tabular}




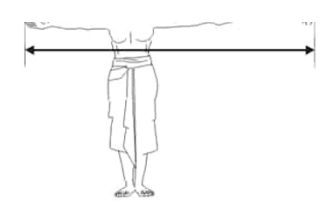

(a)

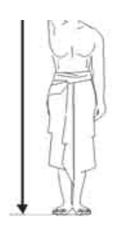

(b)

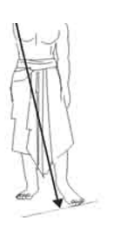

(c)
$6 \begin{array}{lll}\text { 10x9 } & \text { Dwaja } & \begin{array}{l}\text { Ayu } \\ \text { (baik) }\end{array}\end{array} \quad \begin{aligned} & \text { Rumah untuk: Dewa, } \\ & \text { Paryangan, Sanggar }\end{aligned}$

\begin{tabular}{lllll}
\hline & Sx8 & Singa & $\begin{array}{l}\text { Ayu } \\
\text { (baik) }\end{array}$ & $\begin{array}{l}\text { Rumah untuk: Satriya, } \\
\text { Wesya }\end{array}$
\end{tabular}

Gambar 3. Sistem pengukuran SDHM (sukat depa+hasta+musti) dari kiri ke kanan: (a) Depa Alit, (b). Depa Madya dan (c). Depa Agung.

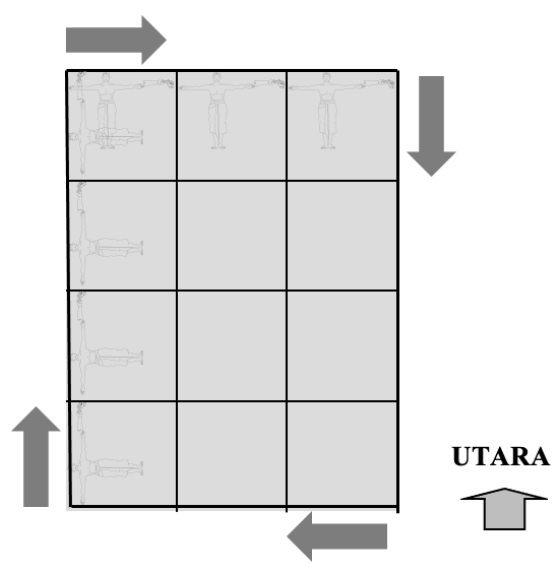

Gambar 4. Hasil pengukuran SDHM (Sukat Depa-Hasta-Musti) dalam ukuran Wreksa (4x3 DHM)

\begin{tabular}{llll}
\hline $8 \times 7$ & Wreksa & $\begin{array}{l}\text { Ayu } \\
\text { (baik) }\end{array}$ & $\begin{array}{l}\text { Rumah untuk: Perbekel, } \\
\text { Prebali,Pande,Pakatik, } \\
\text { Pengalu, wong salah } \\
\text { ujar, Sudra }\end{array}$ \\
\hline
\end{tabular}

(Sumber: Remawa, 2015)

\section{Konsep Sukat Pah Pinara Sanga (SPPS)}

Lontar Ashta Bhumi mensyaratkan bahwa dalam sistem pengukuran berikutnya setelah pengukuran Sukat DepaHasta-Musti (SDHM) selesai, dilanjutkan dengan apa yang disebut dengan sistem pengukuran area yang dibagi sembilan, yang dikenal dengan sebutan Sukat Pah Pinara Sanga (SPPS). Sistem pengukuran ini digunakan untuk menentukan posisi pintu keluar (pemesuan) pada areal hunian Bali Madya. Pembagian awal ini dapat dilihat pada gambar 5 dan selanjutnya untuk menentukan pintu ke luar pada masing-masing area dibagi lagi menjadi 9 area pada ke empat sisi areanya, sehingga pada ke empat sisinya tersebut, terdapat 32 bagian area lengkap dengan nama dan maknanya.

\begin{tabular}{|c|c|c|c|c|}
\hline 2 & $\begin{array}{l}14 \times 13 \\
\text { DHM }\end{array}$ & Dwaja & $\begin{array}{l}\text { Ayu } \\
\text { (baik) }\end{array}$ & $\begin{array}{l}\text { Rumah untuk: Dewa, } \\
\text { Merajan, Sanggar/ } \\
\text { Sanggah, Paryangan, } \\
\text { Panti, Paibon, } \\
\text { Pengastulan, Sad } \\
\text { Kahyangan }\end{array}$ \\
\hline 3 & $\begin{array}{l}13 \times 12 \\
\text { DHM }\end{array}$ & Singa & $\begin{array}{l}\text { Ayu } \\
\text { (baik) }\end{array}$ & $\begin{array}{l}\text { Rumah untuk: Satriya, } \\
\text { Wesya }\end{array}$ \\
\hline 4 & $\begin{array}{l}12 \times 11 \\
\text { DHM }\end{array}$ & Wreksa & $\begin{array}{l}\text { Ayu } \\
\text { (baik) }\end{array}$ & $\begin{array}{l}\text { Rumah untuk: Perbekel, } \\
\text { Prebali,Pande,Pakatik, } \\
\text { Pengalu, Sudra, Tani }\end{array}$ \\
\hline 5 & $\begin{array}{l}11 \times 10 \\
\text { DHM }\end{array}$ & Gajah & $\begin{array}{l}\text { Ayu } \\
\text { (baik) }\end{array}$ & $\begin{array}{l}\text { Rumah untuk: } \\
\text { Brahmana, Bujangga, } \\
\text { Jaksa, Balian, Wesya, } \\
\text { Tumenggung }\end{array}$ \\
\hline
\end{tabular}

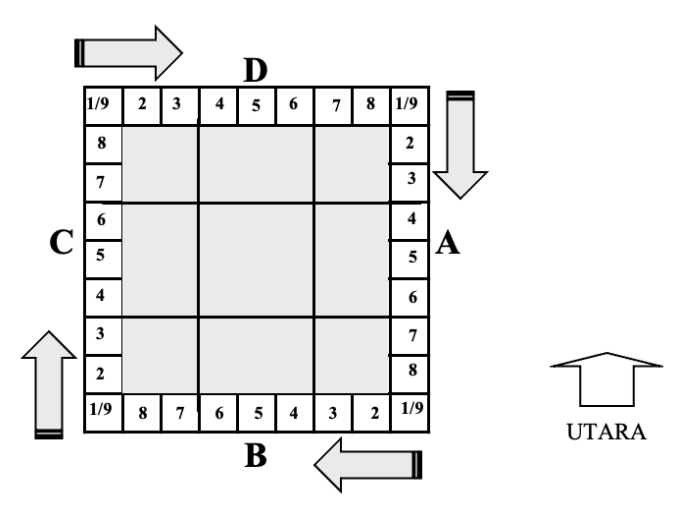

\section{Gambar 5 : Konsep SPPS (Sukat Pah Pinara Sanga)}

Cara memulai pengukuran dalam menentukan pintu ke luar (pemesuan) pada hunian Bali Madya, dimulai dari arah Selatan ke Utara (mangalor-mangetan), dari Utara ke Timur, dari Utara ke Selatan, kemudian dari Timur ke Barat (lihat gambar 5). Jadi, untuk pintu ke luar hunian yang menghadap ke Utara (D), perhitungan pengukurannya dimulai dari Barat ke Timur. Untuk hunian yang menghadap ke Timur (A), perhitungan pintu ke luarnya diukur mulai dari Utara ke Selatan. Hunian yang menghadap ke Selatan (B), perhitungan pintu ke luarnya diukur dari Timur ke Barat dan hunian yang menghadap ke Barat 
(C), perhitungan pintu ke luarnya diukur dari Selatan ke Utara. Dengan melihat sistemnya, maka pergerakan sistem penentuan perhitungan ukuran ini adalah berputar ke kanan atau searah dengan perputaran jarum jam. Sebagai hasil dari analisis grounded theory ini, maka sistem pengukuran pada Sukat Pah Pinara Sanga (SPPS) ini, teorinya dapat dirumuskan seperti pada tabel 2 di bawah. Untuk memberikan pemahaman, maka disertakan juga maksud dari masing-masing istilah yang tertulis pada ke 28 lontar yang diteliti penulis.

Tabel 2. Hasil Pengkodean Selektif Susunan dan Penamaan Sukat Pah Pinara Sanga (SPPS)

SUKAT PAH PINARA SANGA

Perhitungan pembuatan pintu keluar untuk hunian Bali Madya

\begin{tabular}{|c|c|}
\hline $\begin{array}{c}\text { Menghadap ke Utara } \\
\text { diukur dari sisi Barat ke } \\
\text { Timur }\end{array}$ & $\begin{array}{c}\text { Menghadap ke Barat } \\
\text { diukur dari sisi Selatan ke } \\
\text { Utara }\end{array}$ \\
\hline $\begin{array}{l}\text { 1. } \text { Karogan = boros (tidak } \\
\text { baik) } \\
\text { 2. } \text { Tan Panak = tidak } \\
\text { punya anak (tidak baik) }\end{array}$ & $\begin{array}{l}\text { 1. Bhaya Agung = bahaya } \\
\text { besar (tidak baik) } \\
\text { 2. Musuh Makweh = } \\
\text { banyak musuh (tidak } \\
\text { baik) }\end{array}$ \\
\hline $\begin{array}{l}\text { 3. Nohan = celaka miskin } \\
\text { (tidak baik) }\end{array}$ & $\begin{array}{l}\text { 3. Werdhi Mas }=\text { tumbuh/ } \\
\text { murah mas(baik) }\end{array}$ \\
\hline $\begin{array}{l}\text { 4. } \text { Kadalih }=\text { sering } \\
\text { difitnah (tidak baik) } \\
\text { 5. } \text { Kebrahman = panas }\end{array}$ & $\begin{array}{l}\text { 4. Werdhi Guna }= \\
\text { tumbuh/murah guna } \\
\text { (baik) }\end{array}$ \\
\hline $\begin{array}{l}\text { (tidak baik) } \\
\text { 6. } \text { Brahma Stana }=\text { panas }\end{array}$ & $\begin{array}{l}\text { 5. Dhanawan = kaya tapi } \\
\text { boros (tidak baik) }\end{array}$ \\
\hline $\begin{array}{l}\text { (tidak baik) } \\
\text { 7. Suka Mageng = sangat }\end{array}$ & $\begin{array}{l}\text { 6. Brahma Stana }=\text { panas } \\
\text { (tidak baik) }\end{array}$ \\
\hline $\begin{array}{ll} & \text { senang (baik) } \\
8 & \text { Bagva Sih }=\text { dikasihi }\end{array}$ & $\begin{array}{l}\text { 7. } \text { Kinabhakten }= \\
\text { kesetiaan (baik) }\end{array}$ \\
\hline kebahagiaan (baik) & 8. Piutangan $=$ banyak \\
\hline $\begin{array}{l}\text { 9. } \text { Kageringan }= \\
\text { kesakitan (tidak baik) }\end{array}$ & $\begin{array}{l}\text { utang (tidak baik) } \\
\text { 9. Karogo Kala = boros } \\
\text { (tidak baik) }\end{array}$ \\
\hline
\end{tabular}

\begin{tabular}{|c|c|}
\hline $\begin{array}{c}\text { Menghadap ke Selatan } \\
\text { diukur dari sisi Timur ke } \\
\text { Barat }\end{array}$ & $\begin{array}{l}\text { Menghadap ke Timur } \\
\text { diukur dari sisi Utara ke } \\
\text { Selatan }\end{array}$ \\
\hline $\begin{array}{l}\text { 1. Bhaya Agung = bahaya } \\
\text { besar (tidak baik) } \\
\text { 2. Tan Panak= tidak } \\
\text { punya anak (tidak baik) } \\
\text { 3. Suka Mageng = sangat } \\
\text { senang (baik) } \\
\text { 4. Uudan Mas = kekayaan } \\
\text { menyusut (tidak baik) } \\
\text { 5. Brahma Stana = panas } \\
\text { (tidak baik) }\end{array}$ & 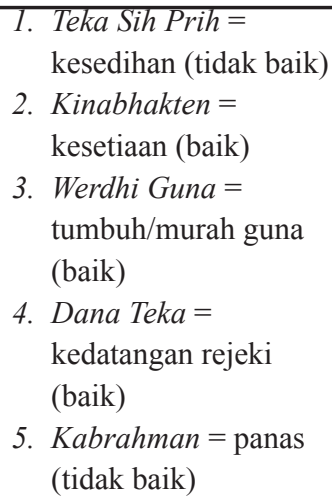 \\
\hline
\end{tabular}

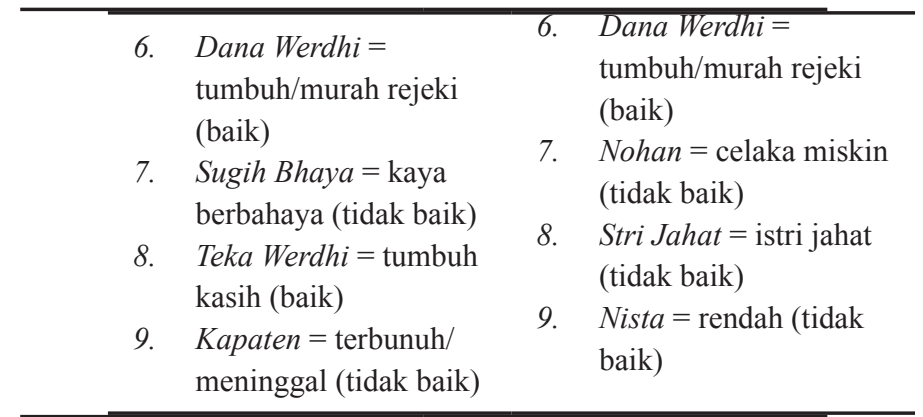

(Sumber: Remawa, 2015)

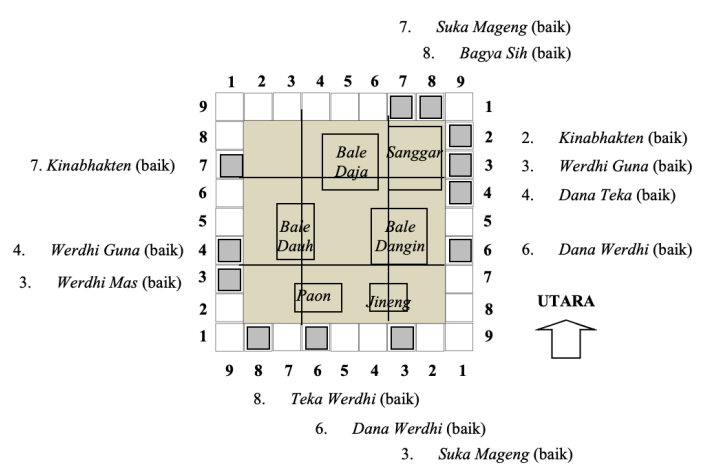

Gambar 6: Lokasi pintu ke luar (pemesuan) yang diperkenankan hasil analisis 28 lontar

\section{Konsep Sukat Tampak (ST)}

Sistem pengukuran ini terdiri dari dua jenis pengukuran, yaitu pengukuran Sukat Natar (SN) dan Sukat TampakNgandang (STN). Pengukuran Sukat Natar/Natah hanya menggunakan satuan tampak saja dan digunakan untuk menentukan jarak antara Bale Dangin dengan Bale Dauh dan jarak Paon dengan Bale Daja.). Sistem pengukuran ini digunakan untuk menentukan jarak antara bale-bale, dari bebaturan satu ke bebaturan bangunan lainnya. Lebih jelasnya akan diuraikan satu persatu sebagai berikut.

\section{Konsep Sukat Natar/Natah}

Konsep Sukat Natar/Natah digunakan untuk mengatur keluasan halaman hunian Bali Madya, dengan memperhitungkan jarak dari bale Dangin ke bale Dauh dan dari bale Delod (pawon) ke bale Daja (paturon). Khusus untuk pengaturan ini hanya menggunakan ukuran tapak/tampak saja, tanpa adanya tambahan/pengurip tampak-ngandang. Berdasarkan data dan faktanya, arah pengukurannya selalu dimulai dari arah Timur ke Barat dan dari arah Selatan ke Utara. Dalam sistem pengukuran ini hanya ada satu ukuran yang 'tidak baik' untuk diterapkan yaitu ukuran lima tampak. Berdasarkan hasil penelitian maka dapat dirumuskan sistem perhitungan Sukat Natar/ Natah ini dalam tabel 3. 
Tabel 3. Menentukan Luas Halaman Dengan Sistem Tampak Pada Sukat Natar/Natah

\begin{tabular}{|c|c|c|c|c|}
\hline NO & $\begin{array}{c}\text { NAMA } \\
\text { Ukuran } \\
\text { dari Bale } \\
\text { Dangin ke } \\
\text { Bale Dauh }\end{array}$ & MAKNA & $\begin{array}{c}\text { NAMA } \\
\text { Ukuran dari } \\
\text { Bale Delod } \\
\text { (pawon) ke } \\
\text { Bale Daja } \\
\text { (Meten) }\end{array}$ & MAKNA \\
\hline 1 & 2 tampak & Kweh bakti/banyak kehormatan & 3 tampak & Werdi mas/Tumbuh/Murah mas \\
\hline 2 & 3 tampak & Luwih guna/guna baik & 4 tampak & Luwih suka/suka baik \\
\hline 3 & 4 tampak & Werdi mas pirak/murah mas perak & 8 tampak & Kweh teka jenek/ banyak datang dan menetap \\
\hline 4 & 5 tampak & Kebrahman/panas & 16 tampak & Suka mageng/besar sukanya \\
\hline 5 & 6 tampak & Werdi dana/tumbuh/murah dana & 20 tampak & Werdi suka/tumbuh/murah kesukaan \\
\hline 6 & 12 tampak & Sugih mas/kaya mas & 23 tampak & Kasukan teka luwih/kesenangan datang baik \\
\hline 7 & 13 tampak & Luih dana/dana baik & 24 tampak & Werdi mas pirak/tumbuh/murah mas perak \\
\hline 8 & 14 tampak & Danawan/kaya tapi boros & 26 tampak & $\begin{array}{l}\text { Suka bukti luwih/luwih dana/kesukaan, makanan, } \\
\text { baik/dna baik }\end{array}$ \\
\hline 9 & 16 tampak & Werdi bukti/tumbuh/murah makanan & 28 tampak & Kweh teke jenek/ banyak datang dan menetap \\
\hline 10 & 21 tampak & Luwih yasa/kemuliaan & 36 tampak & $\begin{array}{l}\text { Suka bakti luwih/luwih suka/kesukaan, } \\
\text { kehormatan, baik/suka baik. }\end{array}$ \\
\hline 11 & 22 tampak & Kweh bakti/ banyak kehormatan & 40 tampak & Suka teka mageng/Kesukaan besar datang \\
\hline 12 & 23 tampak & Luwih guna/guna baik & & \\
\hline 13 & 24 tampak & $\begin{array}{l}\text { Werdi mas pirak/tumbuh/murah mas } \\
\text { perak }\end{array}$ & & \\
\hline 14 & 25 tampak & Luwih suka/Kesukaan & & \\
\hline 15 & 26 tampak & Luwih dana/ dana baik & & \\
\hline 16 & 32 tampak & Sugih mas/kaya mas & & \\
\hline 17 & 33 tampak & Werdi guna/tumbuh/murah guna & & \\
\hline 18 & 34 tampak & Danawan/kaya tapi boros & & \\
\hline 19 & 40 tampak & $\begin{array}{l}\text { Kweh teka jenek/banyak datang dan } \\
\text { menetap }\end{array}$ & & \\
\hline
\end{tabular}

(Sumber: Remawa, 2015) 
Pengukurannya dapat dilakukan dengan menyusun telapak kaki kiri dan kanan secara bergantian seperti contoh berikut untuk mengukur jarak dari bale Delod (pawon) atau dapur ke bale Daja (meten). Modelnya dapat dilihat pada gambar 7 berikut ini. Cara mengukurnya dimulai dari kaki kiri dan kemudian dilanjutkan dengan kaki kanan.

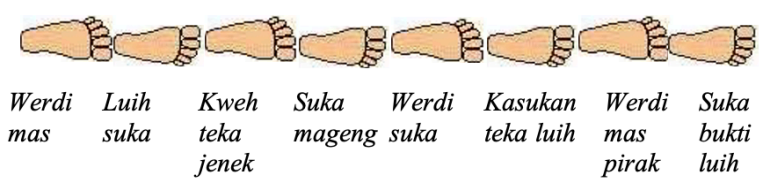

Gambar 7: Sukat Tampak

\section{Konsep Sukat Tampak Ngandang (STN)}

Pengukuran dengan sistem Tampak-Ngandang terdiri dari dua sistem pengukuran yang disebut Sukat Ashta Bhuana (SAB) dan Sukat Astha Wara (SAW). Kedua sistem pengukuran ini digunakan untuk mengukur jarak dari Bale Daja ke Bale Dangin dan antar Bale-Bale di dalam pekarangan rumah tinggal tradisional Bali.

\section{Konsep Pengukuran Ashta Bhuana}

Konsep Ashta Bhuana adalah sistem pengukuran dengan tujuh perhitungan dan menggunakan telapak kaki penghuni. Ukuran ini khusus digunakan untuk menentukan jarak di antara bangunan Bale Daja (paturon) ke bangunan bale Dangin (bale gede). Konsep ini juga sering disebut sukat pengalah atau ukuran yang harus disiapkan atau sukat pahembang atau ukuran keluasan. Sistem perhitungannya berjumlah tujuh bagian dan menggunakan ukuran tampakngandang. Hasil penelitian untuk pengukuran yang menggunakan perhitungan Sukat Ashta Bhuana (SAB) ini dapat ditampilkan pada tabel 4.

Tabel 4. Sistem Perhitungan Sukat Ashta Bhuana (Sab) Dari Bale Daja/Paturon-Bale Dangin

\begin{tabular}{lll}
\hline No & Nama Ukuran & \multicolumn{1}{c}{ Makna } \\
\hline 1 & Bale Banyu & $\begin{array}{l}\text { Kedatangan banyak tamu } \\
\text { (datengan), baik }\end{array}$ \\
\hline 2 & $\begin{array}{l}\text { Sanggar } \\
\text { Waringin }\end{array}$ & $\begin{array}{l}\text { Warga pada masuk (pauban } \\
\text { kadang warga) }\end{array}$ \\
\hline 3 & Gedong Simpen & $\begin{array}{l}\text { Baik, hemat, bisa kaya, (rahayu, } \\
\text { inih, olih sugih) }\end{array}$ \\
\hline 4 & $\begin{array}{l}\text { Macan } \\
\text { Pancuran }\end{array}$ & $\begin{array}{l}\text { Sering difitnah terus menerus } \\
\text { (pisuna tan pegat) }\end{array}$ \\
\hline & $\begin{array}{l}\text { Gajah } \\
\text { palesungan }\end{array}$ & $\begin{array}{l}\text { Baik, cepat berbuah, namun } \\
\text { sering kecurian (ayu, gelis nadi, } \\
\text { nanging sering keparan maling) }\end{array}$ \\
\hline
\end{tabular}

\begin{tabular}{lll}
\hline 6 & Warak Kauron & $\begin{array}{l}\text { Tidak baik (Tukaran tanpa kala), } \\
\text { kapepekin bhuta kala dengen, } \\
\text { kalau hamil sering keguguran. }\end{array}$ \\
\hline 7 & $\begin{array}{l}\text { Gedang } \\
\text { Punggul }\end{array}$ & $\begin{array}{l}\text { Tidak baik, sakit, mati (pati } \\
\text { kojarnia), sering ngaben. }\end{array}$ \\
\hline
\end{tabular}

(Sumber: Remawa, 2015)

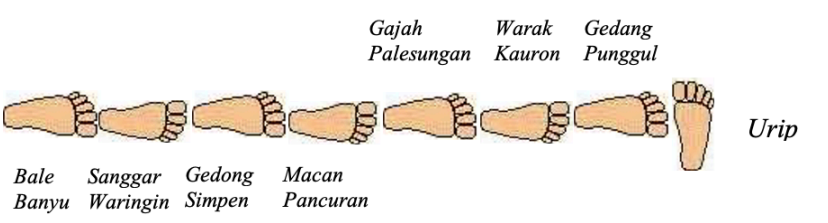

Gambar 8: Sukat Tampak-Ngandang Ashta Bhuana

\section{Konsep Astha Wara}

Konsep Astha Wara adalah konsep pengukuran dalam delapan perhitungan waktu seperti: 1). Sri, 2). Indra, 3). Guru, 4).Yama, 5). Ludra, 6). Brahma, 7). Kala dan 8). Uma. Penentuan sistem ukuran ini dimulai dari pinggir paduraksa yang terdapat di bagian Timur bangunan suci, kemudian diikuti pengukurannya pada bangunan lainnya yang terdapat di Sanggah/Sanggar/Pemerajan. Setelah penentuan tempat suci, kemudian dalam penentuan jarak hunian bangunan (bale-bale), ditentukan dari bataran Bale Daja (meten, gunung rata) yang dianggap sebagai paturon (bangunan yang harus diikuti/dibuat pada tahap pertama). Pengukuran ini menggunakan telapak kaki pemilik yang disebut ukuran tapak/tampak-ngandang yaitu panjang telapak kaki ditambah dengan lebar telapak kaki sebagai penghidup (pengurip). Bangunan yang menjadi paturon (bangunan yang harus diikuti pada tahap pertama) sistem ini adalah pawon/dapur (pebrahman). Lebih jelasnya dapat dilihat pada tabel 5 berikut. Khusus untuk ukuran Tampak Ngandang yang menggunakan sistem Astha Wara tidak perlu dilakukan pengkodean berporos dan selektif, karena ke 28 lontar menyatakan kesamaan sehingga kebenarannya bisa diterima. Sistem ini digunakan untuk pengukuran jarak antar pelinggih (di sanggar/pemerajan), dan antar Bale pada hunian bangunan Bali Madya. Misalnya dari Sanggar ke Paturon (bale meten) menggunakan ukuran Guru, dari Paturon ke Bale Dauh menggunakan ukuran Kala, dari Bale Dauh ke Pawon menggunakan ukuran Brahma dan dari Pawon ke Jineng menggunakan ukuran Sri. Lebih jelas dapat dilihat pada tabel 5 
Tabel 5. Sistem Perhitungan Sukat Asta Wara

\begin{tabular}{llll}
\hline \multicolumn{1}{c}{$\begin{array}{c}\text { Ukuran } \\
\text { Astawara }\end{array}$} & \multicolumn{1}{c}{ Fungsi } & $\begin{array}{l}\text { Sistem } \\
\text { ukuran }\end{array}$ & \multicolumn{1}{c}{ Fungsi } \\
\hline Sri & jarak dari dapur - lumbung & Sri & $\begin{array}{l}\text { Untuk ukuran dapur, lumbung, } \\
\text { pepenggak, warung dan tempat bahan. }\end{array}$ \\
\hline Indra & Jarak antar tempat suci & Kerta & $\begin{array}{l}\text { Untuk ukuran dapur, lumbung, } \\
\text { pepenggak, warung dan tempat bahan. }\end{array}$ \\
\hline Guru & $\begin{array}{l}\text { Jarak dari tempat suci - paturon (meten, } \\
\text { gunung rata })\end{array}$ & Sura & Untuk kandang kuda \\
\hline Yama & Jarak antar tempat suci, patengahan & Kala & $\begin{array}{l}\text { Untuk kandang kerbau, sapi yang } \\
\text { ditempatkan di bagian barat rumah. }\end{array}$ \\
\hline Ludra & Jarak antar tempat suci, tempat bahan & Kali & Pamali tidak bisa digunakan. \\
\hline Brahma & Jarak dari bale dauh - dapur & - & - \\
\hline Kala & Jarak dari paturon - bale dauh, taksu & - & - \\
\hline Uma & Jarak antar tempat suci, paturon & - & - \\
\hline
\end{tabular}

(Sumber: Remawa, 2015)

Cara pengukuran dalam bentuk Sukat Tampak-Ngandang (STN) dapat ditunjukkan sebagai berikut.

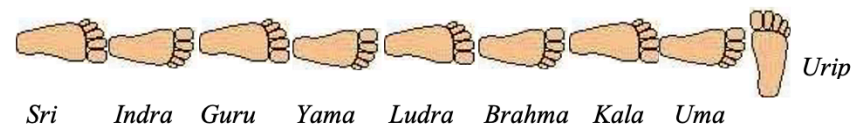

Gambar 9: Sukat Tampak- Ngandang Astha Wara

\section{Konsep Sukat Tampak Guli (STG)}

Konsep Sukat Tampak Guli adalah sistem pengukuran yang khusus digunakan untuk menentukan jarak dari dapur/pawon ke lumbung, dari lumbung/jineng/gelebeg ke pepenggak, warung, tempat bahan, kandang kuda, kerbau, sapi dan kandang babi. Konsep ini hanya ada pada sebahagian kecil lontar Ashta Bhumi yang diteliti, namun sangat penting untuk diuraikan dalam sistem pengukuran lay out ruang hunian rumah tinggal tradisional Bali ini. Sistem pengukurannya menggunakan disebut; Sri, Kerta, Sura, Kala, Kali. Pengukuran ini menggunakan tampakguli, yaitu menggunakan ukuran telapak kaki pemilik dengan tambahan satu ruas jari (a guli) bagian tengah pada jari tengah. Untuk lebih jelasnya uraian dan makna dalam sistem pengukuran ini dapat dideskripsikan dalam tabel 6 .

Tabel 6. Sistem Perhitungan Sukat Tampak Guli (STG)

\begin{tabular}{cl}
\hline $\begin{array}{c}\text { Sistem } \\
\text { ukuran }\end{array}$ & \multicolumn{1}{c}{ Fungsi } \\
\hline Sri & $\begin{array}{l}\text { Untuk ukuran dapur, lumbung, pepenggak, } \\
\text { warung dan tempat bahan. }\end{array}$ \\
\hline Kerta & $\begin{array}{l}\text { Untuk ukuran dapur, lumbung, pepenggak, } \\
\text { warung dan tempat bahan. }\end{array}$ \\
\hline Sura & Untuk kandang kuda \\
\hline
\end{tabular}

\begin{tabular}{cl}
\hline Kala & $\begin{array}{l}\text { Untuk kandang kerbau, sapi yang ditempatkan } \\
\text { di bagian barat rumah. }\end{array}$ \\
\hline Kali & Pamali tidak bisa digunakan. \\
\hline
\end{tabular}

(Sumber: Remawa, 2015)

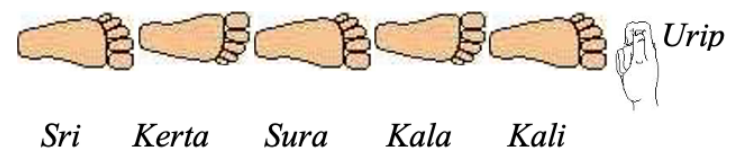

Gambar 10: Sukat Tampak-Guli

Memperjelas aplikasi kelima konsep dasar pengukuran Ashta Bhumi di atas, maka dapat digambarkan dalam sebuah contoh lay out ruang, dalam denah bangunan hunian rumah tinggal tradisional Bali Madya yang diambil dari salah satu contoh kasus penelitian di Kabupaten Gianyar sebagai berikut:

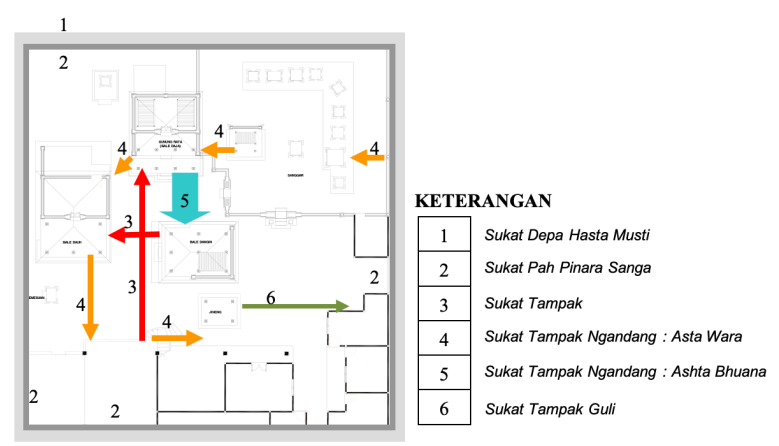

Gambar 11: Denah dan Peruntukan Konsep 


\section{SIMPULAN}

Berdasarkan hasil penelitian, maka dapat disimpulkan bahwa yang menentukan sistem perancangan lay out ruang bangunan hunian rumah tinggal tradisional Bali Madya dalam konsep Ashta Bhumi adalah menggunakan perhitungan SDHM (Sukat Depa-Hasta-Musti) yang dipakai untuk menentukan keluasan areal dan lay out pekarangan bangunan hunian. SPPS (Sukat Pah Pinara Sanga) yang digunakan untuk menentukan posisi pintu keluar (pemesuan). ST (Sukat Tampak) seperti SN (Sukat Natar/Natah) yang digunakan untuk menentukan luas halaman hunian (natah), dari Bale Dangin ke Bale Dauh dan dari Bale Delod ke Bale Daja. Perhitungan STN (Sukat Tampak-Ngandang) seperti SAB (Sukat Ashta Bhuana) dan SAW (Sukat Asta Wara), digunakan untuk menentukan jarak antara bangunan (bale-bale) dari Bale Daja ke Bale Dangin, dan antara bangunan bale-bale lainnya yang lebih kecil. Sedangkan STG (Sukat Tampak Guli) adalah pengukuran yang khusus digunakan untuk menentukan jarak bangunan tertentu dari pawon, jineng ke kandang, pepenggak dan warung.

Ashta Bhumi untuk menentukan sonasi horizontal di atas tanah menggunakan ukuran Sukat Depa-Hasta-Musti (SDHM) dengan berbagai ukurannya seperti; Gajah, Dwaja, Singa dan Wreksa. Areal dengan ukuran 15x14 DHM disebut Gajah, areal dengan ukuran 14x13 DHM disebut Dwaja, areal dengan ukuran 13x12 DHM disebut Singa dan areal dengan ukuran 12x11 DHM disebut Wreksa beserta kelipatannya. Sistem pengukuran lainnya menggunakan satuan Tampak dan Tampak-Ngandang (Ashta Bhuana dan Asta Wara) serta Tampak-Guli. Ukuran Ashta Bhuana terdiri dari tujuh bagian yaitu: 1. Bale Banyu, 2. Sanggar Waringin, 3. Gedong Simpen, 4. Macan Pancuran, 5. Gajah Palesungan, 6. Warak Kauron dan 7. Gedang Punggul. Ukuran Asta Wara terdiri dari delapan bagian yaitu: 1.Sri, 2. Indra, 3. Guru, 4. Yama, 5. Ludra, 6. Brahma, 7. Kala, 8. Uma. Ukuran Tampak-Guli terdiri dari lima bagian yaitu: 1. Sri, 2. Kerta, 3. Sura, 4. Kala, 5. Kali.

Sistem pengukuran SPPS untuk menentukan pintu keluar (pemesuan) dan yang dianggap baik lebih jelasnya dapat dilihat pada gambar 6 di atas. Untuk hunian yang menghadap ke Utara, pintu keluarnya ada pada bagian ke 7 dan 8. Bila huniannya menghadap ke Timur, maka pintu keluar yang dianggap baik adalah pada bagian ke 2, 3, 4 dan 6. Bila huniannya menghadap ke Selatan, maka pintu keluar yang dianggap baik adalah pada bagian ke 3, 6 dan 8, sedangkan bila hunian menghadap ke Barat, maka yang dianggap baik untuk pintu keluar adalah pada bagian ke 3, 4 dan 7. Sistem pengukuran ini masih berlangsung sampai saat ini walaupun huniannya tidak termasuk dalam Sukat Satus dan Sukat Satak sistem hunian rumah tinggal tradisional Bali Madya. Artinya pada bangunan modern sekarang, sistem pembagian pintu ke luar ini masih diterapkan.

\section{DAFTAR RUJUKAN}

Endraswara, Suwardi (2006), Metodologi Penelitian Kebudayaan, Gadjah Mada University Press, Yogyakarta.

Gelebet, (1985), Arsitektur Tradisional Bali, Departemen Pendidikan dan Kebudayaan Propinsi Daerah Tk I Bali.

Handanamangkara, SPH. (1964), Primbon Jawa Sabda Guru, Penerbit Keluarga Soekarno, Solo.

Lukman Ali, (1994), Kamus Besar Bahasa Indonesia, Penerbit Balai Pustaka, Jakarta.

Remawa, A.A.Gede Rai (2015), Konsep Estetika Dan Ruang Pada Gubahan Bangunan Bali Madya, Disertasi Sekolah Pascasarjana ITB Bandung.

Suharsana, IB.Putu Arta, (1997), Indik Swakarma, Ashta Bhumi, Ashta Kosala Kosali, Salinan Lontar, Takmung Klungkung.

Subandia, (1990), Sukat Karang, Alih Aksara Lontar, Kantor Dokumentasi Budaya Bali, Denpasar.

Wijayananda, Ida Pandita Mpu Jaya, (2004), Tata Letak Tanah dan Bangunan, Pengaruhnya Terhadap Penghuninya, Paramita Surabaya.

\section{Lontar:}

Lontar Usana Bali

Lontar milik, Griya Anyar Peling Gianyar.

Lontar milik I Wayan Subumi, Br. Mantring Petak Gianyar. Lontar milik, A.A.Gd. Rai Santha, Puri Kaleran Br. Tengah, Tps. Gianyar.

Lontar milik, Ida Pedanda Made Telaga, Griya Sanur Delod Pasar, Dps.

Lontar milik, Griya Gede Pamedilan, Br. Tegallunggah Pamecutan, Dps.

Lontar milik I Made Kaler, Pemangku Pura Pahuman, Sgguan Tonja Dps.

Lontar milik, Griya Bandar Tegal Ubung Denpasar.

Lontar milik, Griya Subagan Karangasem.

Lontar milik, Griya Jelantik, Subagan Karangasem, (Koleksi Pusdok).

Lontar milik, Jero Tegal Sidemen, Karangasem.

Lontar milik, Griya Tegal Sidemen, Karangasem.

Lontar milik, I Dewa Putu Singarsa, Br. Kawan Manggis Karangasem.

Lontar Milik, Ida Made Agung, Budakeling, Karangasem. Lontar milik, Ida Bagus Putu Arta Suharsana, Batu Tabih Takmung, Klk.

Lontar milik, Pemangku Pura Puseh, Megati Kelod, Tabanan

Lontar milik, Griya Anyar Singaraja, Buleleng.

Lontar milik, PT.Seraya Bali Style Batubulan Gianyar.

Lontar milik, I Wayan Budagotama, Wisma Santibrata, 
Banjar Mantring Kangin Petak Gianyar

Lontar milik, Gedong Kertya Singaraja asal lontar dari Br Sintrig, Abiansemal Badung

Lontar milik, Gedong Kertya, Singaraja Bali, asal lontar dari I Gusti Ketut Kerdu, Desa Prasi Bugbug Karangasem. Lontar milik, Gedong Kertya Singaraja, asal lontar dari I Ketut Ginarse, Banjar Paketan, Singaraja.

Lontar milik, Ida Bagus Arsana, Jl. RSAD RT VII/40 Denpasar Bali, asal lontar dari Griya Ageng Tangguwisia, Kecamatan Seririt, Buleleng.

Lontar milik, Ida Pedanda Putu Pemaron, Griya Makasaputra, Kendran Tegallalang Gianyar.

Lontar milik, Pusdok Bali, asal lontar dari Griya Anyar Singaraja.

Lontar milik, Ida I Dewa Gede Catra, asal lontar dari Ida bagus Putu Arka Suhardana, Griya Batu Tabih Klungkung. Lontar milik, Ida Bagus Made Lodra, Griya Puseh Sanur Denpasar Bali.

Lontar milik, Pemangku Pura Puseh Br. Batuaji Kawan Kaja Desa Sembung Gede Kerambitan

Lontar milik, Gedong Kertya Singaraja, Kesalin oleh I Ketut Romiasta dari Banjar Paketan asal lontar dari Ajin Ida Kerta, Omah Hijau Marga Kerta 